\title{
Management of Training on the 2013 Curriculum for IPA Teachers Through Partnership Program in Boalemo District, Gorontalo Province
}

\author{
Anik Wismiarti 1,a*, Yatim Riyanto ${ }^{1, b}$, and Erny Roesminingsih 1,c \\ ${ }^{1}$ Department of Education Management, Postgraduate of State University of Surabaya, Surabaya, Indonesia \\ a anikwismiarti123@gmail.com; b jatimriyanto@gmail.com; ' cernyroesminingsih@unesa.ac.id \\ ${ }^{*}$ Corresponding Author
}

How to Cite : Wismiarti, A., Riyanto, Y., Roesminingsih, E., (2019). Management of Training on the 2013 Curriculum for IPA Teachers Through Partnership Program in Boalemo District, Gorontalo Province. International Journal for Educational and Vocational Studies, 1 (7), 805-812. DOI: https://doi.org/10.29103/ijevs.v1i7.1776

\section{ARTICLE HISTORY}

Received: 7 September 2019

Revised: 28 September 2019

Accepted: 19 October 2019

\section{KEYWORDS}

Empowerment;

Partnership program;

On the job learning;

2013 Curriculum

\begin{abstract}
The purpose of the science teacher training program organized by the Ministry of Education and Culture with Empowerment of partner 1 teachers through the partnership program is to improve the ability of partner 2 teachers in understanding and applying science learning in accordance with the 2013 curriculum. The Training Method is On The Job Learning with a pattern of pairing more competent teachers (having high Teachers Competency Test/UKG scores and coming from developed regions) called partner teacher 1 with teachers deemed not competent (having low UKG scores and coming from disadvantaged areas) called partner teacher 2. The sample of this study was a science teachers' at SMP Negeri 1 Tilamuta (Middle School) and SMP Negeri 1 Wonosari, Boalemo Regency, Gorontalo Province. The results obtained, a collaborative program through partnerships in basic education teachers with training methods on work learning partner teachers in Boalemo district 2 in Gorontalo province who initially did not understand and never applied the 21st Century Learning Implementation Plan (RPP) specifically Discovery Learning learning models and models Project Based Learning $(\mathrm{PjBI})$ is understood and able to implement it in the classroom even though it still feels strange. Students also become happy with the model implemented by the 2 teacher's partners in the class. The interview results show that at SMP 1 Tilamuta Boalemo, $94 \%$ of students were happy with the lessons given by the teacher. While in SMP 1 Wonosari Boalemo as many as $90 \%$ of students said they were happy with sustainable learning.
\end{abstract}

This is an open access article under the CC-BY-SA license.

\section{INTRODUCTION}

Based on the results of the Teacher Competency Test (UKG) held by the Educational Quality Assurance Institute (LPMP) of the Ministry of Education and Culture (Kemendikbud) in 2015 showed a gap in the quality of education in Indonesia, which is indicated by the results of UKG teachers in 24 provinces below the average value $(<$ 53.05), whereas only ten provinces have UKG scores above the average ( $>53.05$ ). The results of the 24 provinces are far below the standard value of 70 . The UKG results also show that there are $30 \%$ or 5,094 out of 17,138 teachers who have not yet reached the graduation standard.

The gap in the quality of education can also be shown in the inequality of the results of the distribution of students' National Examination (UN) scores. Provinces that have a low average UKG teacher score indicate low student average scores in the UN and produce a negative deviation or a decrease in UN scores from 2016 to 2017.
One example of this can be shown in Gorontalo Province. The mean UKG score of teachers in Gorontalo Province only reached 48.88, while the highest UN score of students in Mathematics in 2016 reached 49.21 and decreased in 2017 ie the value achieved was 48.24 . This shows that the low competency and quality of teachers has an impact on the low quality of education, which is shown in the low UN scores obtained by students.

Based on these problems, an effort is needed from the Ministry of Education and Culture in improving and equating teacher competencies and quality to achieve an even distribution of quality in education quality. The efforts made by the Ministry of Education and Culture in addressing the imbalance of teacher competency and quality are through empowerment or the process of providing opportunities and responsibilities for teachers to think, act, speak, and make decisions related to their work to increase the potential of teachers who have not met 
competencies that are sufficiently following which are expected.

Empowerment, according to Wallerstein (Lord and Hutchiosn, 1993), is a social process that involves the participation of individuals, organizations, and society to increase individual and community control to improve the quality of people's lives. The purpose of empowerment is to involve an active role in participants in the process of change, not only implementing projects but also in organizing activities. Participants can assist in identifying and measuring problems, as well as playing a role in assessing and evaluating data. The results of the evaluation must be shared together as feedback to the community in the decision-making process and policy towards the main objectives. This approach, according to Lincoln and Guba, requires both quantitative and qualitative methods used in the evaluation process (Zimmerman, 2000: 45). The empowerment process can help someone in increasing their abilities so that they can do problem-solving and decision making independently. (Zimmerman, 2000: 46).

The Empowerment conducted by the Ministry of Education and Culture aims to improve the quality and competence of educators. The development of human resources of an organization aims to improve the effectiveness and efficiency of the work of human resources (HR) in achieving work program goals (Martoyo, 2000). The intended employee development is through increasing knowledge and skills through Education and Training (Diklat). Training is an effort to improve performance and increase employee potential, which is carried out to train skills and be prepared to be able to perform the functions and duties of employees (Harsuko, 2016: 152). Education is a process, technique, and method of teaching and learning to transfer knowledge. Education is more philosophical and theoretical (Hamali, 2016).

Ministry of Education and Culture's efforts in developing human resources are through partnership programs. The collaboration program through the partnership of primary education teachers with the training method on the job learning. Darling-Hammond and Bransford in Musfah stated that teacher training programs must pay attention to the real needs of teachers related to their function as instructors and educators, not merely to provide theoretical abilities. One of the training methods, according to Dessler (2000), is on the job training (training in the workplace), training for employees to learn a job while doing it. Bradley, et al. in Musfah also suggested that in-service training (on-the-job learning) is essential to ensure that changes are useful for students and that schools can deal with inadequacies certainty with confidence.

The partnership program for primary education teachers with the on the job learning method is by pairing more competent teachers from advanced schools (called partner teachers 1) with teachers who are seen to be incompetent from underdeveloped schools (called partner teachers 2). In this case study, partner two natural science teachers from Boalemo district Gorontalo will partner with a science subject teacher from Surabaya. The two partner teachers in the Boalemo Gorontalo natural science study area are from Tilamuta 1 Middle School and 1 Wonosari Middle School. Teacher partners 1 in the study of the natural sciences came from SMP Negeri 37 Surabaya. Furthermore, partner teacher two will be given empowerment to improve competency in partner teacher 3 with ten people. Partner 3 teachers are teachers who are in one province.

The strategic aim of empowerment by the Ministry of Education and Culture in the partnership program is to increase teacher competency in the 2013 Curriculum (K13) to adjust curriculum changes, especially in graduate competency standards, content standards, process standards, and assessment standards.

Ministry of Education and Culture Regulation No. 22 of 2016 concerning process standards states that the process standard is a criterion regarding the implementation of learning in education units to achieve graduate competency standards. The learning process in the education unit should be conducted interactively, inspirational, fun, challenging, motivating students to participate actively, as well as providing sufficient space for the initiative, creativity, and independence by the talents, interests, and physical and psychological development of students.

To achieve process standards, the teacher is someone who has a role in designing, implementation, and evaluating learning. Designing learning means that teachers are required to make plans for the implementation of learning to be done. The learning plan prepared by the teacher is called the Learning Implementation Plan (RPP). According to Permendikbud Number 65 of 2013 concerning Process Standards, the Learning Implementation Plan (RPP) is a face-to-face learning plan for one or more meetings. The lesson plan is developed from the syllabus to direct the learning activities of students in an effort to achieve Basic Competence.

$21^{\text {st }}$ Century education is education that integrates knowledge skills, skills, and attitudes, as well as mastery of ICT. These skills can be developed through various models of activity-based learning in accordance with the characteristics of competencies and learning materials. The skills needed in the 21st Century are also higher-order thinking skills or called Higher Order Thinking Skills (HOTS), which are very necessary for preparing students to face global challenges. Therefore, the implementation of $21^{\text {st }}$ or $4 \mathrm{~K}$ century skills development (critical thinking and problem solving, communication, creativity, and innovation, Collaboration), literacy, and PPK (Strengthening Character Education) must be raised in the $21^{\text {st }}$ Century RPP.

The models and methods that will be used in $21^{\text {st }}$ century learning are required to be more multi-model and 
multi-method and more of a real-world problem. Permendikbud No. 103/2014 explains that the 2013 curriculum uses three main learning models that are expected to shape scientific behavior, social behavior, and develop a sense of curiosity. The three models are the problem-based learning model (Problem based learning), the project-based learning model (Project-based learning), and the learning model through disclosure/discovery (Discovery/Inquiry learning). This learning model must also be raised in the $21^{\text {st }}$ Century RPP.

Empowerment (empowerment) conducted by the Ministry of Education and Culture on teachers aims to meet the needs of equal distribution of education quality through increasing the competence and quality of in districts/cities that have UKG values below the standard. The benefits obtained by the empowerment are increasing the competence of partner two and partner three teachers in developing and implementing 21st-century lesson plans with Project-Based Learning (PjBL) and Discovery Learning (DL) learning models to improve the quality of teacher education that has not yet reached the standard competency.

\section{METHODS}

\subsection{Design of Activities}

Implementation of teacher empowerment through partnership programs can be presented as Chart 1. The partnership program starts with preparatory activities through a coordinating meeting by the Ministry of Education and Culture with each Regional Government. The next activity is the training activities for Partner teachers 1 . The target achievements of this phase of the activity include: (1) partner teacher 1 understands the substance of the partnership program, and the duties of partner teacher 1 in each stage; (2) partner one teachers are skilled in facilitating the strengthening of junior secondary teacher capacity through partnership programs; and partner teacher 1 has material for facilitation at each stage of the junior secondary teacher partnership.

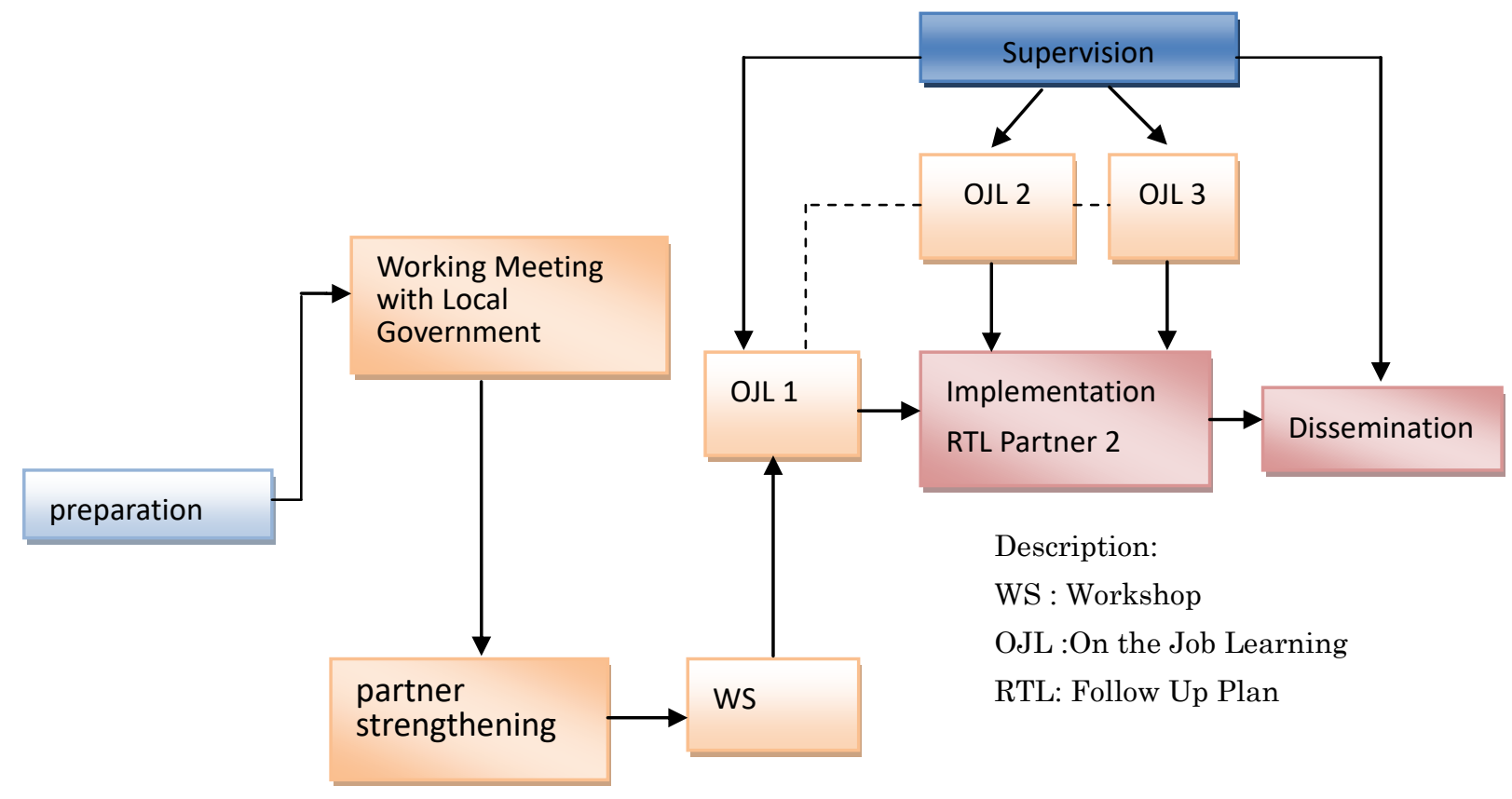

Figure 1. Stages of Partnership Program Implementation

Educational activities provided are in the form of workshops (WS), conducted by Mitra 1 teachers and Mitra II teachers aimed at building a shared perspective between partner 1 teachers and partner 2 teachers, so that each participant understands the substance and stages of partnership activities. The training activities are realized in the form of on the job learning (OJL). OJL activities are divided into three, namely OJL 1, OJL 2, and OJL 3.

In the empowerment process, the evaluation phase is carried out on supervision and dissemination activities. Supervision is carried out to evaluate OJL 1 activities with targeted targets including: (1) text of the results of monitoring of OJL activities 1,2,3 and dissemination; (2) partner teachers 1,2 and 3 get feedback on matters that should be improved based on OJL activities and dissemination; and (3) OJL supervision and dissemination report. The dissemination activity is the delivery of best practice, so that teacher partners 1,2 and 3 get information and can utilize the information.

OJL 1 activities are carried out with partner teachers 2 conducting training in partner teacher schools 2 . OJL 1 activities have milestone targets including: (1) partner 2 teachers have good relations with residents of partner teacher 1 schools; (2) partner teacher 2 knows the keys to educational success in partner teacher school 1; (3) partner 2 teacher can fulfill his own shortcomings in making syllabus and lesson plans on the subjects he is 
taking; (4) partner teacher 2 understands the class situation and conditions of partner teacher 1; (5) partner teacher 2 gets lessons on things that must be prepared before learning; (6) Follow-up Draft (RTL) documents were agreed by partner 1 teachers and facilitators or resource persons; and (7) partner teacher 2 obtains important lesson information in OJL 1.

OJL 2 activities are carried out by partner 2 teachers and partner 1 teachers in partner teacher schools 2 . OJL 2 activities and RTL Implementation by partner 2 teachers have achieved targets including: (1) partner 2 teachers get mentoring by partner 1 teachers for RTL implementation; (2) partner teacher 2 gets information about things that must be improved in learning; (3) partner 2 teachers can observe partner 1 teacher learning practices; (4) partner teacher 2 has a draft of the best practice document from the partnership; (5) monthly RTL implementation report in the form of files sent to Pania online; and (6) the results set forth in the RTL can be achieved $100 \%$.

OJL 3 activities carried out by partner 2 teachers to partner 3 teachers in partner 2 and 3 teacher provinces. OJL 3 activities have achieved targets including: (1) RTL activities of partner 2 teachers can be $100 \%$ realized; (2) the problems faced by partner teachers 2 and 3 in implementing the RTL; (3) have an understanding of the problems and ways of solving the discussion of the RPP that will be carried out in the partner teacher class 3 ; (4) partner teachers 2 and 3 get good lessons from teaching practices in partner 3 teacher classes; (5) the formulation of a sustainable strategy for implementing partner teachers' RTL implementation 2; (6) RTL partner teacher implementation report 2; and (7) manuscript for best practice partner teacher 2 .

\subsection{Object Scope}

Study subjects are people who provide information, both about themselves and others or an event to researchers. Informants also means people who can provide information or information about the problem being studied and can act as a resource during the research process takes place (Koentjaraningrat, 1994: 86). The subjects in this study were IPA partner 1 teacher at SMPN 37 Surabaya, IPA partner teacher 2 at SMP 1 Tilamuta and SMP 1 Wonosari Boalemo Gorontalo.

\subsection{Study Place}

The places used in this study are at SMP Negeri 37 Surabaya and at Boalemo Gorontalo, namely at SMP Negeri 1 Tilamuta and Wonosari Boalemo Gorontalo.

\subsection{Data Collection Technique}

The type of observation used in this study is observation of active participation, ie the researcher comes to the place of the person who is the object of research, and is actively involved with all activities carried out by the informant. Observations in this emporement activity are shown in the supervision activities carried out by partner 1 teachers to partner 2 teachers. In this study, researchers observed learning activities that are the way the teacher teaches in class and completeness in teaching.

Interview technique used in this study is unstructured interviews or known as in-depth interviews. The data asked in the interview process is about making and implementing the Learning Learning Model RPP and Project Based Learning.

Focus Group Discussions are conducted by facilitators or resource persons to conduct evaluations and supervision of partner teachers 1,2 and 3. The survey is a primary data collection activity through giving questions to respondents, in order to gather information from groups that represent a population. The survey in this study was conducted for students at SMPN 1 Tilamuta and SMP 1 Wonosari Boalemo Gorontalo, in order to obtain an evaluation of the results of competency and quality improvement activities through on the job learning to partner teachers 2 .

\subsection{Research Instruments}

This study uses two instruments used in the data collection process, including:

\section{Likert scale}

Likert scale is used when conducting supervision and evaluation activities at the interview, FGD, and survey stages. Supervision conducted by partner 1 teachers to partner 2 teachers and facilitators to partner 1, 2, and 3 teachers using a Likert scale. Likert scale is used to measure opinions about social phenomena. The likert scale of supervision by the facilitator is aimed at evaluating aspects of OJL implementation and aspects of achieving OJL targets, while the likert scale of supervision by partner teacher 1 is intended for the assessment of partner teacher 2 in behavioral aspects and substance aspects of OJL 2.

\section{Reflection sheet}

The reflection sheet is the result of observation activities carried out by partner teacher 1 to partner teacher 2 . The reflection sheet describes data that reflects the implementation and achievements of the partnership program.

\subsection{Analysis Technique}

This research uses a qualitative approach with descriptive type. A qualitative approach is research that produces descriptive data in the form of written or oral words from people and observed behavior (Sitorus, 1998: 205). Based on data collection techniques performed, the analysis techniques used by researchers are data reduction, conclusion drawing, and proportion analysis. Data reduction is an analysis that sharpens, classifies, directs, or discards unnecessary data and organizes data so that final conclusions can be drawn, while proportion analysis 
is an analytical technique used to draw conclusions in the form of survey results and Likert scale.

\section{RESULTS AND DISCUSSION}

\subsection{Supervision Results by Partner Teachers 1}

Based on the results of interviews and observations made by researchers as partner teachers 1 the following results were obtained:

1. Partner teachers 2 before participating in partnership activities.

Table 1. Results of Analysis of Existing Partner Teacher Conditions 2 Before the Partnership Program

\begin{tabular}{clcc}
\hline No. & \multicolumn{1}{c}{ Interview results } & $\begin{array}{c}\text { Teacher } \\
\text { Partner } 2 \\
\text { Middle School } \\
1 \text { Tilamuta } \\
\text { Boalemo }\end{array}$ & $\begin{array}{c}\text { Teacher } \\
\text { Partner 2 } \\
\text { Middle } \\
\text { School 1 } \\
\text { Wonosari } \\
\text { Boalemo }\end{array}$ \\
\hline 1 & $\begin{array}{l}\text { Understand the } 2013 \\
\text { curriculum }\end{array}$ & Yes & Yes \\
\hline 2 & $\begin{array}{l}\text { Understand the revised } \\
\text { edition } 2013 \text { curriculum }\end{array}$ & No & No \\
\hline 3 & $\begin{array}{l}\text { Understand the } 21^{\text {st }} \\
\text { century RPP development }\end{array}$ & No & No \\
\hline 4 & $\begin{array}{l}\text { Know the } 21^{\text {st }} \text { Century } \\
\text { Learning Model }\end{array}$ & No & No \\
\hline 5 & $\begin{array}{l}\text { Implement a } 21^{\text {st }} \text { century } \\
\text { learning model }\end{array}$ & No & No \\
\hline
\end{tabular}

2. The results of coaching teacher partner 1 to partner teacher 2 when participating in partnership activities

Table 2. Results of Partnership Program Implementation

\begin{tabular}{clcc}
\hline No & $\begin{array}{l}\text { Partner teacher training 1 for } \\
\text { partner teacher 2 }\end{array}$ & $\begin{array}{c}\text { Coaching } \\
\text { partner } \\
\text { teachers 1 }\end{array}$ & $\begin{array}{c}\text { Mastery of } \\
\text { partner } \\
\text { teachers 2 }\end{array}$ \\
\hline 1 & $\begin{array}{l}\text { Partner teacher 1 provides an } \\
\text { understanding of changes in } \\
\text { the 2013 curriculum }\end{array}$ & Done & Could \\
\hline 2 & $\begin{array}{l}\text { Partner teacher 1 provides } \\
\text { revised edition 2013 } \\
\text { curriculum material }\end{array}$ & Done & Could \\
\hline 3 & $\begin{array}{l}\text { Partner teacher 1 gives 21st } \\
\text { century lesson plans }\end{array}$ & Done & Could \\
\hline 4 & $\begin{array}{l}\text { Partner teacher 1 gives an } \\
\text { example of a 21st century } \\
\text { lesson plan }\end{array}$ & Done \\
\hline 5 & $\begin{array}{l}\text { Partner teacher 1 provides the } \\
\text { Inquiry learning model } \\
\text { material }\end{array}$ & Done & Could \\
\hline 6 & $\begin{array}{l}\text { Partner teacher 1 gives } \\
\text { examples of lesson plans with } \\
\text { Inquiry learning models }\end{array}$ & $\begin{array}{l}\text { Partner teacher 1 gives an } \\
\text { example of lesson plans with a } \\
\text { problem based learning model }\end{array}$ & Done \\
\hline & $\begin{array}{l}\text { Partner teacher 1 provides } \\
\text { problem based learning }\end{array}$ & Could \\
\hline
\end{tabular}

\begin{tabular}{|c|c|c|c|}
\hline & project based learning model & & \\
\hline 11 & $\begin{array}{l}\text { Partner teacher } 1 \text { gives the } \\
\text { Discovery learning model } \\
\text { material }\end{array}$ & Done & Could \\
\hline 12 & $\begin{array}{l}\text { Partner teacher } 1 \text { gives an } \\
\text { example RPP with the } \\
\text { learning model Discovery } \\
\text { learning }\end{array}$ & Done & Could \\
\hline 13 & $\begin{array}{l}\text { Partner teacher } 1 \text { carries out } \\
21 \text { st century learning using } \\
\text { the Project based Learning } \\
\text { learning model }\end{array}$ & Done & Could \\
\hline
\end{tabular}

3. Partner teacher 2 builds 21st century lesson plans using one of the 21st century learning models both in partner 1 teacher schools and in partner 2 teacher schools

Table 3. Results of Making Teacher Partner RPP 2

\begin{tabular}{|c|c|c|c|}
\hline No & Teacher name & School Origin & $\begin{array}{c}\text { The chosen } \\
\text { learning model }\end{array}$ \\
\hline 1 & $\begin{array}{l}\text { Siti Luthfah } \\
\text { Ridwan, S.Pd, } \\
\text { M.Pd }\end{array}$ & $\begin{array}{c}\text { SMP Negeri } 1 \\
\text { Tilamuta } \\
\text { Boalemo }\end{array}$ & $\begin{array}{l}\text { Discovery } \\
\text { Learning }\end{array}$ \\
\hline 2 & $\begin{array}{l}\text { Ni Ketut } \\
\text { Budiani, S.Pd, } \\
\text { M.Pd }\end{array}$ & $\begin{array}{c}\text { SMP Negeri } 1 \\
\text { Wonosari } \\
\text { Boalemo }\end{array}$ & $\begin{array}{l}\text { Project Based } \\
\text { Learning }\end{array}$ \\
\hline
\end{tabular}

4. Partner teacher 2 implements 21st century lesson plans using one of the 21st century learning models both in partner 1 teacher schools and in partner 2 teacher schools

Table 4. Results of Implementing Partner Teacher RPP 2

\begin{tabular}{clll}
\hline No. & Teacher name & $\begin{array}{c}\text { Learning } \\
\text { model }\end{array}$ & \multicolumn{1}{c}{ Material } \\
\hline \multirow{2}{*}{1} & $\begin{array}{l}\text { Siti Luthfah } \\
\text { Ridwan, S.Pd, }\end{array}$ & $\begin{array}{l}\text { Discovery } \\
\text { Learning }\end{array}$ & $\begin{array}{l}\text { 1. Addictive substance } \\
\text { 2. Animal classification }\end{array}$ \\
& M.Pd & & \\
\hline 2 & Ni Ketut & Project & 1. Various substances \\
& Budiani, & Based & 2. Mixed Separation \\
& S.Pd, M.Pd & Learning & \\
\hline
\end{tabular}

5. Making lesson plans and implementing lesson plans by partner teachers 2

Table 5. Analysis Results of CSP Development and Implementation Activities

\begin{tabular}{llll}
\hline No. & Teacher name & School Origin & \multicolumn{1}{c}{ Making RPP } \\
\hline & Siti Luthfah & SMP Negeri 1 & It's good, only the \\
Ridwan, S.Pd, & $\begin{array}{l}\text { Tilamuta } \\
\text { M.Pd }\end{array}$ & Boalemo & $\begin{array}{l}\text { a little trouble } \\
\text { pouring out ways for } \\
\text { students to find their } \\
\text { own concepts in the } \\
\text { lesson plan because } \\
\text { the teacher is }\end{array}$ \\
& & & $\begin{array}{l}\text { accustomed to using } \\
\text { the lecture method } \\
\text { (LKPD) }\end{array}$ \\
& & & $\begin{array}{l}\text { It's good, only the } \\
\text { teacher is still having } \\
\end{array}$ \\
& & & a little trouble \\
& & pouring out ways for \\
& & students to find their \\
\hline
\end{tabular}


own concepts in the lesson plan because the teacher is accustomed to using the lecture method (LKPD)

6) Table of comparison results of GM 2 learning supervision before and after mentoring

Table 6. Comparison Results of Supervision of Learning Before and After Mentoring

\begin{tabular}{|c|c|c|c|}
\hline \multirow[b]{2}{*}{ No } & \multirow{2}{*}{$\begin{array}{c}\text { Indicators of } \\
\text { learning success } \\
\text { with the DL and } \\
\text { PjBL models }\end{array}$} & \multicolumn{2}{|c|}{ Implementation } \\
\hline & & $\begin{array}{c}\text { Before } \\
\text { Assistance }\end{array}$ & $\begin{array}{c}\text { After } \\
\text { Mentoring }\end{array}$ \\
\hline 1 & Preliminary & & \\
\hline $\mathrm{a}$ & $\begin{array}{l}\text { Condition a } \\
\text { pleasant learning } \\
\text { atmosphere }\end{array}$ & Done & Done \\
\hline $\mathrm{b}$ & $\begin{array}{l}\text { Linking material } \\
\text { that has been } \\
\text { previously studied } \\
\text { with material that } \\
\text { will be studied as } \\
\text { apperception }\end{array}$ & Done & Done \\
\hline $\mathrm{c}$ & $\begin{array}{l}\text { Delivering the } \\
\text { competencies to be } \\
\text { achieved and an } \\
\text { outline of the } \\
\text { activities to be } \\
\text { carried out }\end{array}$ & Done & Done \\
\hline 2 & Core activities & & \\
\hline $\mathrm{a}$ & $\begin{array}{l}\text { Able to provide } \\
\text { stimulation / } \\
\text { stimulation }\end{array}$ & did not happen & Done \\
\hline $\mathrm{b}$ & $\begin{array}{l}\text { Able to provide } \\
\text { problem } \\
\text { identification }\end{array}$ & did not happen & Done \\
\hline $\mathrm{c}$ & $\begin{array}{l}\text { Able to direct } \\
\text { students in data } \\
\text { collection }\end{array}$ & Done & Done \\
\hline$d$ & $\begin{array}{l}\text { Able to direct } \\
\text { students in data } \\
\text { processing }\end{array}$ & Done & Done \\
\hline $\mathrm{e}$ & $\begin{array}{l}\text { Able to help } \\
\text { students to prove / } \\
\text { find their own } \\
\text { concepts / verify }\end{array}$ & did not happen & $\begin{array}{l}\text { did not } \\
\text { happen }\end{array}$ \\
\hline $\mathrm{f}$ & $\begin{array}{l}\text { Able to direct } \\
\text { students in making } \\
\text { conclusions }\end{array}$ & did not happen & Done \\
\hline
\end{tabular}

\subsection{The Results of Supervision by the Facilitator}

Based on the assessment by 2 facilitators or resource persons, the following results are obtained through frequency or proportion analysis.

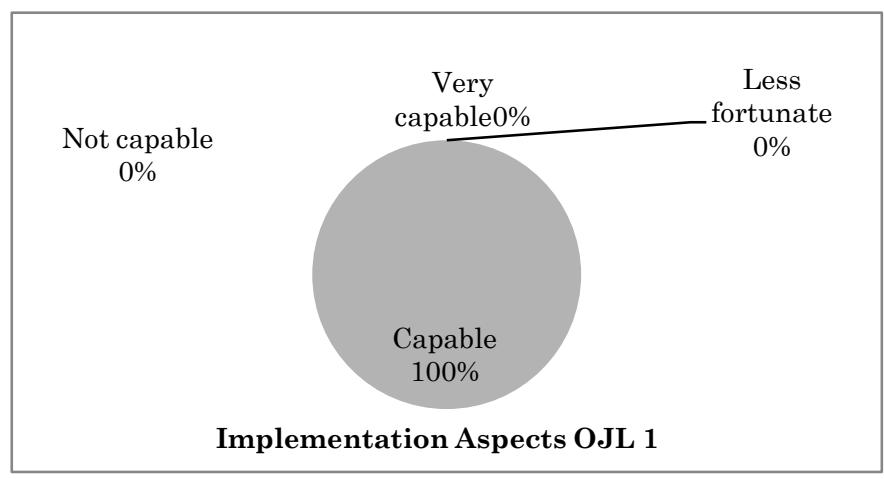

Figure 2. Results of Supervision of OJL 1 Facilitator Activities to Partner Teachers 2 in the Aspect of Implementation and Target Achievement

\section{Implementation of OJL 1 partner teacher1}

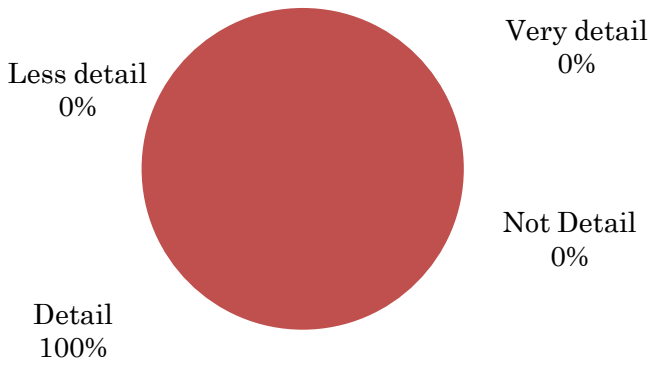

Figure 3. Results of Supervision of OJL 1 Activities for Partner Teachers 1

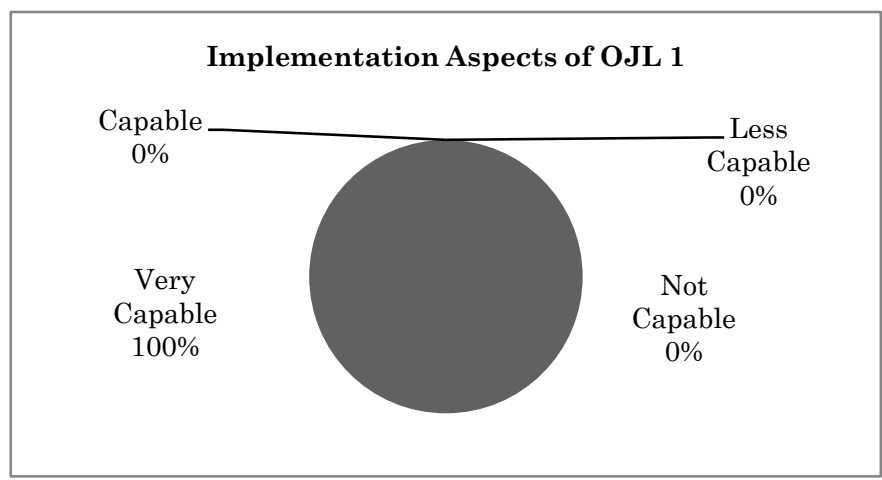

Figure 4. Results of OJL 2 Facilitator's Supervision of Partner Teachers 2 in the Implementation Aspect and Target Achievement Aspect

\subsection{Survey Results By Students}

Students responses from the results of survey activities by partner 1 teachers to the application of discovery learning and Project based Learning models implemented by partner 2 teachers in class as follows. 


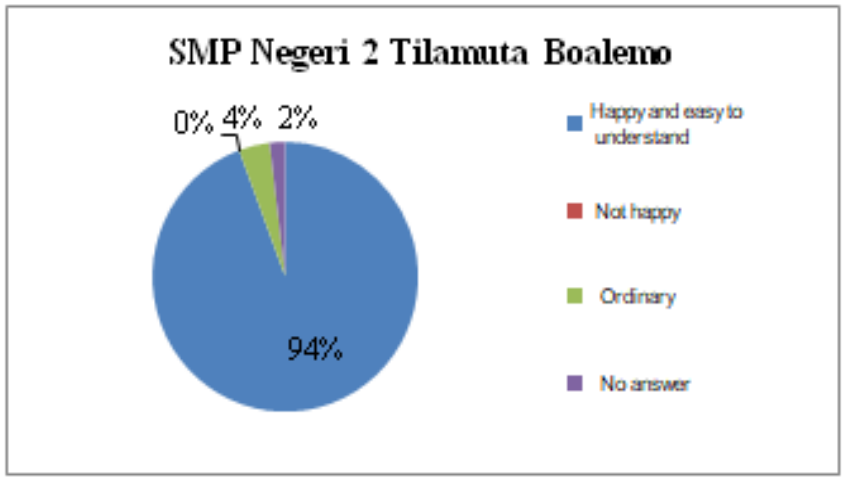

Figure 5. Student Response Results at Tilamuta Boalemo Middle School 2 towards the Partnership Program

\section{SMP Negeri 1 Wonosari Boalemo}
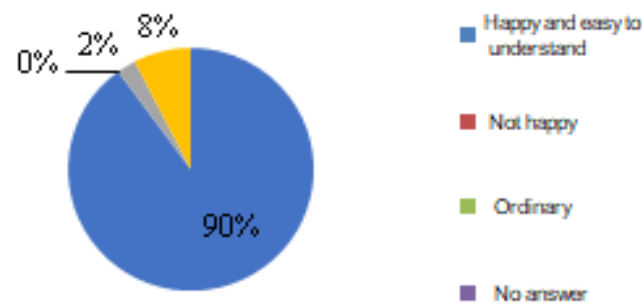

Figure 6. Student Response Results at Wonosari Boalemo 1 Junior High School on the Partnership Program

\section{Discussion}

The empowerment process undertaken by the Ministry of Education and Culture in the context of developing human resources through education and training (Diklat) partnership programs is in line with the role of the Ministry of Education and Culture in conducting academic supervision on improving the quality of education. Based on Law No. 20 of 2003 concerning the National Education System, it explicitly states that there is a need for quality assurance of education. Outline targets in the Kemendikbud partnership program include (1) curriculum development; (2) improvement of the learning process; and (3) teacher professional development. The partnership program also includes five academic supervision functions (Satori, 2016: 65) namely: (1) research function to find out the situation and conditions in the world of education, (2) assessment function for evaluation aspects; (3) the repair function to determine the corrective action; and (4) the function of improvement is in terms of quality improvement (CQI).

Empowerment conducted by the Ministry of Education and Culture is by empowering the human resources (HR) of educators to play an active role and participate in improving the quality of education for $\mathrm{HR}$ other educators who require increased competence. The method of developing teacher human resources in the empowerment program is through the Partnership Training Program.

Based on the results of observations and interviews in the field, in broad outline, the conditions of the existing partner 2 teachers both in SMP Negeri 1 Tilamuta and SMP Negeri 1 Wonosari Bolaemo as shown in Table 3.1 are familiar with the 2013 curriculum, but do not understand the implementation and implementation of the 2013 revised curriculum into learning and do not yet understand the application of RPP and 21st-century model learning. As for the results of the partnership activities, it was concluded that partner one teacher was able to carry out teacher guidance to partner teacher two which included: (1) revision edition of 2013 curriculum, (2) briefing of RPP 21st century; and (3) provisioning of the $21^{\text {st }}$ century learning model. Partner 2 teachers have been assessed to be able to master the material and training delivered by partner one teachers, as shown in Table 2 .

The 21st-century learning model chosen by partner two teachers at SMP Negeri 1 Tilamuta Boalemo Discovery Learning partner two teachers at SMP Negeri 1 Wonosari Boalemo chose the Project-Based Learning learning model as can be presented in Table 3. Partner teacher two is considered capable of carrying out lesson plans but is still experiencing problems in developing students to be able to find their own concepts because partner teacher 2 is still accustomed to using the lecture method, as can be presented in Table 3.5. The achievement indicators that have not been successfully implemented are in helping students to prove/find their own concepts/verify, as can be presented in Table 6. Based on the supervision activities carried out by the facilitators in OJL 1 and OJL 2 activities, partner one teachers were considered to have provided mentoring to partner two teachers in detail as presented in Figure 2 and 4 and had an impact on partner two teachers to be able to achieve achievement indicators the parnership program as shown in Figure 1 and 3.

Based on the results of the analysis and evaluation, it can be concluded that the empowerment of teacher human resource enhancement through training activities on the job learning in partnership programs, is able to change partner two teachers who initially did not understand, did not understand and never even carried out 21st-century RPP especially learning models Discovery Learning and learning models Project-based learning becomes aware of the learning model and is considered capable of implementing it in the classroom even though it still seems unfamiliar.

Learners also become happy with the model applied by partner two teachers in their class. From the results of interviews as can be presented in Graph 3.5 and Graph 3.6 seen in SMP 1 Tilamuta Boalemo 94\% of students were happy with the lessons given by the teacher, while in SMP 1 Wonosari Boalemo as many as 90\% of students expressed satisfaction with the learning that took place. Through this partnership program partner teacher, two are also expected to teach all the abilities obtained from the guidance of partner teacher 1 to partner teacher 3 . So 
that disparities or gaps that are too far between education in Eastern and Western Indonesia can be adequately overcome.

\section{CONCLUSION}

1) Implementation of Training on the job learning through a partnership program can improve the ability of partner teachers in 2 districts of Boalemo, Gorontalo Province in making and implementing RPP 21st Century Project-Based Learning (PjBL) and Discovery Learning (DL) models

2) The results of training on the job learning: (a) Partner teacher two can make RPP models of Discovery Learning and Project-Based Learning; (b) Teacher partner 2 is able to carry out learning with the Discovery Learning model and Project-Based Learning; (c) Students are happy with the model applied by partner two teachers in their class. From the interview results, it is seen in SMP 1 Tilamuta Boalemo $94 \%$ of students feel happy with the lessons given by the teacher. While in SMP 1 Wonosari Boalemo as many as $90 \%$ of students expressed satisfaction with the learning that took place.

\section{REFERENCES}

Bodgan, Robert dan Steven J. Taylor. 1993. Kualitatif Dasar-Dasar Penelitian. Surabaya :Usaha Nasional

Hamali, Aril Yusuf. 2016. Pemahaman Manajemen Sumber Daya Manusia: Strategi Mengelola Karyawan. Jakarta: PT Buku Seru

Harsuko, Riniwati. 2016. Manajemen Sumber Daya Manusia: Aktivitas Utama dan Pengembangan SDM. Malang: UB Press

Lord, Jhon dan Hutchison, Peggy. 1993. The Process of Empowerment: Implication for Theory and Practice. Canadian Journal of Community Mental Health

Permendikbud. 2013. Permendikbud nomor 65 tahun tentang standar proses. Jakarta : Badan Standar Pendidikan Nasional

Suherman, dkk. (2001). Common TexBook Strategi Pembelajaran Matematika Kontemporer. Bandung: Jurusan Pendidikan Matematika UPI Bandung

Sugiyono. 2005. Metode Penelitian Kualitatif. Bandung: Alfabeta

diunduh tanggal 20 November 2018 pukul 11.00 wib

Martoyo, Susilo. 2000. Manajemen Sumber Daya Manusia Edisi 4. Yogyakarta: BPFE- Yogyakarta

Musfah, Jejen. Pelatihan Profesional: Mengembangkan Kompetensi Guru. Fakultas Ilmu Tarbiyah dan Keguruan (FITK) UIN Syarif Hidayatullah

Zimmerman, Marc A. 2012. Empowerment Theory. University of Michigan 